\title{
Reflective Writing of Mexican EFL Writers: Levels of Reflection, Difficulties and Perceived Usefulness
}

\author{
Ruth Roux ${ }^{1}$, Alberto Mora $^{2} \&$ Axel Tamez ${ }^{3}$ \\ ${ }^{1}$ Professor of Applied Lingusitcs, Universidad Autonoma de Tamaulipas, Mexico \\ ${ }^{2}$ Professor of the Center for Languages and Applied Lingusitics, Universidad Autonoma de Tamaulipas, Mexico \\ ${ }^{3}$ Professor of English as a Foreign Language, Universidad Autonoma de Tamaulipas, Mexico \\ Correspondence: Ruth Roux, Olivos 1140, Fraccionamiento Las Huertas, Victoria, Tam., C. P. 87025, Mexico. \\ Tel: 52-834-316-6232. E-mail: rrouxr@uat.edu.mx
}

Received: April 18, 2012 Accepted: May 10, 2012 Online Published: June 28, 2012

doi:10.5539/elt.v5n8p1 URL: http://dx.doi.org/10.5539/elt.v5n8p1

The research is financed by the Program for Faculty Improvement of the Mexican Ministry of Education (PROMEP).

\begin{abstract}
This case study examined the level of reflection in the essays written by 15 Mexican English language teachers taking a Master's Degree course in English as a foreign language (EFL). The essays were evaluated using the categorization scheme for assessing the level of reflection developed by Kember, et al. (2008). Semi-structured interviews were held with information-rich participants to investigate the difficulties experienced with reflective writing and the usefulness attributed to this academic genre. Findings suggest that the categorization scheme is applicable to reflective writing in EFL, although almost half of the participants continued to write in a non-reflective mode throughout the course. Low level of proficiency in English, lack of familiarity with reflective writing, challenges of deductive reasoning, and the absence of productive feedback were their reported difficulties. Reflective writing was deemed useful because it facilitates participation in class discussion, a more thorough completion of course readings, the adoption of a stance towards SLA theories, and improvement of academic writing ability.
\end{abstract}

Keywords: reflective writing, foreign languages, teacher education, reflective teaching, assessment

\section{Introduction}

The importance of reflection in teacher education is well established (Dewey, cited in Rodgers, 2002; Hatton \& Smith, 1995; 2002; Schön, 1987). It is claimed that reflection gives meaning to teaching experience (Dewey cited in Rodgers, 2002); helps generating knowledge from practice (Hiebert, Gallimore, \& Stiegler, 2002); improves classroom practice (Bartlett, 1990); and facilitates the integration of theory and practice (Shin, 2006). Specifically in English as a foreign language (EFL) teacher education, pre-service and in-service teachers' ability to reflect is assumed to help teachers move from preconceptions of effective teaching and learning, to a philosophy of teaching consistent with emerging understandings of EFL teaching practice (Crandall, 2000; Richards \& Lockhart, 1996).

Writing is thought to play an important role in reflecting on and understanding experiences in teaching. Van Manen (1997, p. 125), for example, affirms that "Writing fixes out thoughts on paper. It externalizes what in some sense is internal; it distances us from our immediate lived involvements with the things of our world". Fink (2003, p. 117) maintains that reflective writing "focuses on the writer's learning experience itself and attempts to identify the significance and meaning of a given learning experience, primarily for the writer". Writing, therefore, is not only a vehicle for reflection to learn academic content (Boud, 2001), it is also the only means through which teacher educators can analyze student teachers' thinking related to their learning experiences.

Reflective writing is a permanent record of thoughts and experiences (Colton \& Sparks-Langer, 1993) considered useful for both, student teachers and teacher educators. Student teachers can write their thoughts on how to connect theory and practice (Shin, 2006), which prepares them to solve for the problems of a complex world in which they must continually analyze, evaluate, and revise their knowledge in the context of ongoing practice (Weimer, 2002). 
Teacher educators, on the other hand, may use reflective writing as a window to students' thinking and learning. What they view from that window can help them establish and maintain relationships with students (Spalding \& Wilson, 2002), to better facilitate their learning.

Although a variety of tasks can be used to elicit and evaluate reflection (v.gr. case studies, narratives, and journal entries), the reflective essay is the most commonly used in the context in which this study took place. A reflection paper may demonstrate knowledge in a particular content area; however, it not always depicts the students' insights of their biases, or the ways in which they integrate knowledge and application (Ho \& Richards, 1993). Reflection operates at a number of levels (Day, 1993; Jay \& Johnson, 2002; Kember, et al., 2008; King \& Kitchner, 2004; Larrivee, 2008; Reagan et al., 2000; Sparks-Langer, et al., 1990; Van Manen, 1977) and writers may reflect at one level or at several different levels in a single piece of writing. Each level is distinctive in the quality of reflection, moving from trivial or superficial, to substantial or meaningful, to fundamental or deep. Superficial reflection tends to merely reproduce knowledge presented by others, while deep reflection produces a change in perspective of a belief or understanding.

The level of reflection on a piece of writing may be related to a variety of factors; the teaching experience of the student is one of them. Schön (1987) argued that expert practitioners in a profession may be distinguished from novices by their ability to reflect on their practice when they deal with complex or unusual situations. Experts are generally able to reflect deeply to solve unexpected problems, while novices tend to reflect superficially. We should therefore expect to find different levels of reflection on the papers of in-service teachers and in those of pre-service teachers. Reflective writing, however, is a complex ability and even experienced teachers need to be provided with a set of strategies that facilitate the acquisition of the ability in a rather long process. Experienced teachers with and without specific training on reflective writing will also reflect at a different level. As affirmed by Russell (2005, p. 203), "Fostering reflective practice requires far more than telling people to reflect and then simply hoping for the best... reflective practice can and should be taught - explicitly, directly, thoughtfully and patiently_...". To teach reflective practice, a few questions must first be tackled: What do we mean by reflection? How can reflection be taught? How do teacher educators assess reflection?

\section{Literature Review}

\subsection{The Concept of Reflection}

The term reflection has been used in a variety of contexts and there are, therefore, disparities in definitions, frames of reference, and applications (Hatton \& Smith, 1995; Kember, et al., 2008; Rodgers, 2002; Sparks-Langer et al., 1990). The origin of the concept is generally attributed to Dewey (cited in Rodgers, 2002), who considered reflection as a thought process that education should strive to cultivate. Dewey defined reflection as an "active, persistent and careful consideration of any belief or supposed form of knowledge" (Rodgers, 2002, p. 850). Boyd and Fales (1983) define reflection as an internal process that helps the individual refine understanding of an experience, which may lead to changes in perspective. Boud (2001, p. 10), from an experiential learning perspective to adult education, describes reflection as "those intellectual and affective activities which individuals engage in to explore their experiences in order to lead to new understandings and appreciations". Mezirow (1998), who analyzes adult education from a critical theory perspective, considers that reflection that leads to learning needs to be critical, and that reflection is critical only when students make an assessment of what is being reflected upon.

Reflection is generally viewed as an incremental process. The literature on the topic commonly distinguishes three levels of reflection (Day, 1993; Farrell, 2004; Handal \& Lauvas, 1987; Jay \& Johnson, 2002; Van Manen, 1977). In general terms, in the first level the focus is on understanding theories and concepts. In the second level, the focus is on applying theory to practical situations. The third level is that in which the focus is on experimenting a change in perspective of a fundamental understanding.

For the purpose of this study and drawing on the above definitions, we assume that reflection is a thinking process through which experience, beliefs, and knowledge are carefully examined and evaluated to ultimately arrive to new perspectives.

\subsection{Pedagogical Strategies That Foster Reflection}

A variety of teaching strategies are employed in EFL teacher education to foster reflection. Teacher educators involve students in action research projects (Burns, 1999, 2009; Nunan, 1990; Wallace, 1998); case studies and ethnographic studies (Dubin \& Wong, 1990; Van Lier, 1988); microteaching and practicum experiences (Luk, 2008; Wallace, 1991); and structured tasks such as writing reflective journal entries (Bailey, Curtis, \& Nunan, 2001; Lee, 2007; Richards \& Lockhart, 1996; Woodfield \& Lazarus, 1998), peer observations (Day, 1990; 
Richards \& Farrell, 2005; Spada, 1990), narratives (Barkhuizen, 2007), and reflective essays (Ponnudarai et al., 2002). Although reflective tasks can be carried out in written, video or audio taped forms, written reflections are thought to offer the clearest evidence of reflection (Fund, Court \& Kramarski, 2002).

While pedagogical strategies have the potential to encourage reflection, a systematic way to analyse written reflections is needed so that true reflection can be encouraged, responded to, and assessed. Hatton and Smith (2006) claim it is not enough to know that reflection is fostered by a procedure or technique; and teacher educators should be able to specify the levels of reflection that take place. Some students simply describe their experiences while others take a critical step towards analysis (Ho \& Richards, 1993). What we believe is most important for EFL teacher educators is to know the specific situations and conditions that facilitate and those that inhibit the level of reflection that help students acquire new perspectives or understandings.

\subsection{Assessing Reflection}

Assessment of the products of reflection is controversial. Some authors believe that written reflections should not be evaluated because assessment conventions demand that students display their best work to be judged and reflection involves expressing doubts, revealing lack of understanding and focusing on the unknown (Boud, 2001). Others maintain that, in developing reflective thinking, it is essential to determine whether students actually demonstrate the capacity to make reflective judgements through their writing (King \& Kitchener, 2004). We believe that written reflections should be evaluated only when certain conditions have been met for student teachers to benefit from the learning strategy and progress into higher levels of reflection. These conditions include: at least un upper intermediate level of proficiency in English language; a positive belief in the importance of reflection to learn from practice; previous preparation that includes explicit teaching of the language used in reflective writing; opportunities to discuss the issues involved in reflective writing; and sufficient time to write reflectively.

A number of frameworks have been developed that define different levels of reflection (Day, 1993; Jay \& Johnson, 2002; Larrivee, 2008; Van Manen, 1977). As mentioned earlier, frameworks commonly include three distinct levels of reflection. Stated briefly, the first level is concerned with the application of educational knowledge to reach an unquestioned objective in a context viewed as unproblematic. This is the level of technical or practical reflection. The second level, contextual, deliberative or conceptual, is that in which students interpret their experiences, meanings, perceptions, and assumptions in relation to theory. In the last level of reflection, critical, dialectical or transformative, teaching and contexts of teaching are viewed as problematic and student teachers use political, social or ethical criteria to evaluate their experiences.

One scheme was found for assessing the level of reflection, specifically in written work. Kember, et al., (2008) developed a scheme that includes four levels of reflection (see a summary of the scheme on Appendix 1). The first level, habitual action, is non-reflection and occurs when students search for material on a topic and place it on a piece of writing without trying to really understand the underlying concepts. The material may be paraphrased, summarized, or even plagiarized. The second level, understanding, occurs when the student uses a deep approach to learning in the search for the author's underlying meaning. The concepts, however, are understood as theory without relation to real-life experiences or applications. This category does not imply reflection. The third level, reflection, is that in which the writer interprets concepts in connection to personal experiences, and personal insights go beyond book theory. The higher level of reflection, critical reflection, implies undergoing a change in perspective by conducting a critical review of assumptions from conscious and unconscious prior learning. Perspective transformation is difficult to occur; therefore according to Kember, et al. (2008), critical reflection is an uncommon outcome.

This study used the four-category scheme by Kember, et al. (2008) to code the level of reflection in the written papers of four EFL in-service teachers at a Mexican university. The coding scheme was considered appropriate for our study because it was specifically designed to be used on written reflections; the procedures of its validity and reliability are well documented; the categories are thoroughly described; and it was found applicable to texts written in English as a foreign language.

Previous research has examined the levels of reflectivity in the written work of students of biology, chemistry, mathematics and computer sciences (Fund, Court, \& Kramarski, 2002); physical therapy (Plack et al., 2005); and nursing (Wong et al., 1995). Most studies analyze reflection in learning journals. Very few studies have examined the level of reflection in the written work language teachers in English speaking countries; and we could not find research that analyzed reflective essays written in English by native speakers of Spanish. Trying to fill this gap, our study examined the level of reflection in the written work of 14 EFL teachers enrolled in an MA Program in Bilingual Education at a Mexican pedagogical university. The study aimed to respond to the following research questions: 
1. How do participants reflect through their writing in terms of the level of engagement?

2. What were the main difficulties that the participants encountered when writing a reflective paper?

3. How useful do the participants perceive reflective writing for learning theoretical content?

Answers to these questions may be useful for language teachers receiving formal training who are required to write reflective essays; for language teacher educators in the search for strategies to promote higher order reflection and tools to assess teachers' level of reflection; and for researchers in the fields of EFL teacher education and assessment.

\section{Methodology}

This study used case study methodology. A case study is a carefully designed project that systematically collects information about a writing event or a small group of writers for the purpose of exploring, describing or explaining an aspect not previously known or considered (MacNealy, 1999). Case study methodology was considered appropriate because rather than pursuing generalizations, it conserves the natural diversity encountered in classrooms (Bissex, 1990). Also, case studies allow intensive views of individuals and the different factors that influence their behaviors (Bissex \& Bullock, 1987).

\subsection{Context of the Study}

The study was conducted during a 60-hour Second Language Acquisition (SLA) course, in the first of a two-year M. A. Program in Bilingual Education. The course was divided in two parts. The first part drew from cognitive perspectives of SLA (Larsen-Freeman, 2007). The second part of the course focused on sociocultural theories of SLA (Lantolf, 2000). The class met two times a week and consisted of brief lectures, small group and whole group discussions, and short individual or pair work. Materials for the course included SLA textbooks, handouts created by the instructor and electronic presentations. The course included five one-hour sessions of preparation in reflective writing through brief presentations, samples of reflection writing, class discussion and in-class writing activities. Preparation was given by the instructor of the course during the third and the fourth weeks of the 15 -week course.

The MA in Bilingual Education was a new program, implemented because of the need to prepare teachers for the public primary education system. In the year 2001 the State Ministry of Education launched an EFL program for all public primary schools. The first year, the program addressed fourth graders of urban schools only (almost 45,000 students), moving gradually to the rest of the grade levels every year. The first year, 484 teachers were hired and by 2010, the program had 1,850 teachers in all grade levels (Gobierno del Estado de Tamaulipas, 2005-2010). This rapid growth of the demand for EFL teachers and the high levels of unemployment favored the incorporation of undergraduates of all professional fields into the Primary School English Language Program. The only entry requirement was that they could communicate orally in English. Once they were hired, teachers took certification courses or Diploma and MA programs related to English teaching, depending on their perceived needs, financial possibilities and academic interests.

\subsection{Participants}

Participants of the study were 15 EFL teachers with one to fifteen years of teaching experience. They were native speakers of Spanish with ages that ranged from 26 to 54 years. Their first degrees were in pre-school education, elementary education, social sciences education, tourism, informatics, accounting, and public relations. Three teachers self-rated their English language proficiency as B1 and 12 teachers considered they had a B2 level of proficiency, according to the descriptions of the global scale of the Common European Framework of Reference.

\subsection{Reflective Writing Preparation Procedures}

Participants received five hours of preparation for reflective writing, distributed in five different class meetings. The preparation involved five stages. On the first stage, students were given time to write reflection papers about the topic of the class (Krashen's second language acquisition hypotheses), and its relationship to their educational context. They were also given a suggested list of questions to prompt their writing, along with recommendations for free writing. Participants could use the questions as they desired, or not use them at all. The list of questions was the following:

What did I learn in this session?

What are my thoughts and feelings toward the issues we discussed/learned?

How do I connect what I learned today with what I have experienced as a teacher?

How do I connect what I learned today with what I learned in previous courses?

How does my learning contradict or challenge my previous assumptions, ideas or beliefs? 
Reflection essays were read and returned to students with feedback comments in the following class. To avoid feedback comments that could inhibit their writing, the instructor wrote on the margins descriptions of what they were writing about. Examples of the comments provided by the instructor are: "summary of the lesson", "your role as a teacher", and "description of your learning style". A copy of each essay was kept for analysis.

On the second stage of the reflective writing preparation, the instructor gave a 30 minute interactive lecture on the importance of reflection in language teacher education and the ways in which reflection helps learning. A visual presentation guided the talk. Then the students were asked to write for 35 minutes a short reflection on the last topic discussed in class (the concept of input, the optimal input to be used in the classroom and possible difficulties). Then they were asked to finish their papers at home and in the following class they were asked to self-assess their reflections using the scheme by Kember, et al. (2008). The final version of the reflection papers were collected for analysis.

The third stage consisted in talking to students about the organization of written reflections. They were asked to work in pairs to outline a possible structure of a reflection paper. Each pair of students presented their outline on the board and provided a rationale for the suggested structure. Then, the instructor provided a possible structure of a reflective paper which included introduction, a description of the context, narration of an experience, an examination of a concept or theory, and a reflection on the personal insights derived. Students were asked to write a reflection paper at home on the concept of language proficiency and its use in their specific teaching context. Two days later, students were asked to exchange reflection papers and assess a peer's work using the scheme. They were given two days to improve their papers before submitting them. The papers were included in the analysis.

On the fourth stage, the instructor provided a 35 minute interactive presentation on the language of reflection. The focus was on the mixture of academic and personal style involved in reflective writing. Students contributed to the development of two-column chart. One column contained examples of the academic style language that could be used in reflections, and the second column included expressions of personal style considered appropriate in reflective writing. Students were asked to write at home on the meaning of the term bilingual and how it helped understanding their teaching practice. Papers were collected for analysis.

Finally, students read, discussed and made questions related to the prompt for the reflective paper. All doubts were solved and ten days were given to compose the paper, which was submitted electronically. The task that prompted the final reflective paper was worded as follows.

Use your knowledge of the concepts reviewed in class in the design of a classroom activity for the acquisition of vocabulary, pronunciation, speaking, reading or writing. Write a lesson plan that includes the objectives, rationale, materials and procedure of the activity. Then carry-out your lesson in one of your classes. After you finish teaching your lesson, write a three-page reflection paper. Did your lesson result as you expected? In what ways did it result or not result as you expected? How do you explain what happened? What would you do next time? Why? Include in your reflection the theories, concepts and ideas discussed in the course.

Structure your essay in the following way: introduction (describe the aims, materials and procedures of your class), a description of the context (describe your students in detail), the narration of an experience (describe your class), an examination of a concept or theory (explain the concept and how it was applied in practice), and a reflection on the personal insights derived (discuss in depth what you learned of the concept and your teaching experience).

All reflection papers developed by the participants were collected for analysis. Pseudonyms were created for each participant to preserve their anonymity. It is worthwhile mentioning that each essay submission accumulated points for the students' course grades, regardless the level of reflection attained.

\subsection{Data Sources and Analysis}

A total of 75 pieces of writing were the first source of data. The length of the reflection papers developed during the preparation sessions varied from one to three pages; they were hand-written. The final reflective essays were three to four single-spaced printed pages.

The reflective papers were coded with the use of the four-category scheme developed by Kember, et al. (2008). The scheme assumes a holistic approach to coding, which means that assessment of the level of reflection has to be performed at the whole-paper level. This is because generally, a reflective paper contains an introduction, a description of the context, the narration of an experience, an examination of a concept or theory, and a reflection on the personal insights derived. The first sections are supporting material and only the last part is likely to show reflection. Kember, et al. (2008) therefore recommends the examination of the whole paper to find the highest level of reflection.

The researchers independently read and analyzed the papers in terms of level of reflection. Then they met to discuss results. Inter-rater reliability resulted in $85 \%$ of the cases. The researchers discussed their views until they 
agreed on the classification of the 11 papers in which they had not coincided on the first analysis.

The second source of information was a 30-35 minute semi-structured interview with three information-rich participants who were contacted after all papers were classified (see interview protocol on Appendix 1). Information-rich cases are cases from which one can learn and are therefore worthy of in-depth study (Patton, 2002). Information-rich cases were selected using an intensity sampling; one participant from each of the three levels of reflection, according to results of the last reflection paper, was selected for interview. The interviews were held in Spanish, transcribed and translated into English by one of the authors.

The interviews were recorded and transcribed. Transcriptions were coded using the constant comparative method (Glaser \& Strauss, 1967; Strauss \& Corbin, 1998). In conformity with this method, the transcripts were first read to become familiar with their content. Levels of reflection were written next to the text that suggested them. Levels were then analyzed to determine the dominant level of reflection on each piece of writing.

\section{Findings}

\subsection{Levels of Engagement in Reflective Writing}

As a result of the analysis of the reflective papers in terms of level of reflection, $51 \%$ of the 75 pieces of work were classified as "non-reflection", (they showed no evidence of attempt to reach understanding of a concept or theory); $44 \%$ were classified as "understanding" a concept or theory; $3 \%$ were classified as "reflective" (theory was applied to practical situations); and none of the papers showed evidence of a change in perspective. These results are shown on Figure 1.

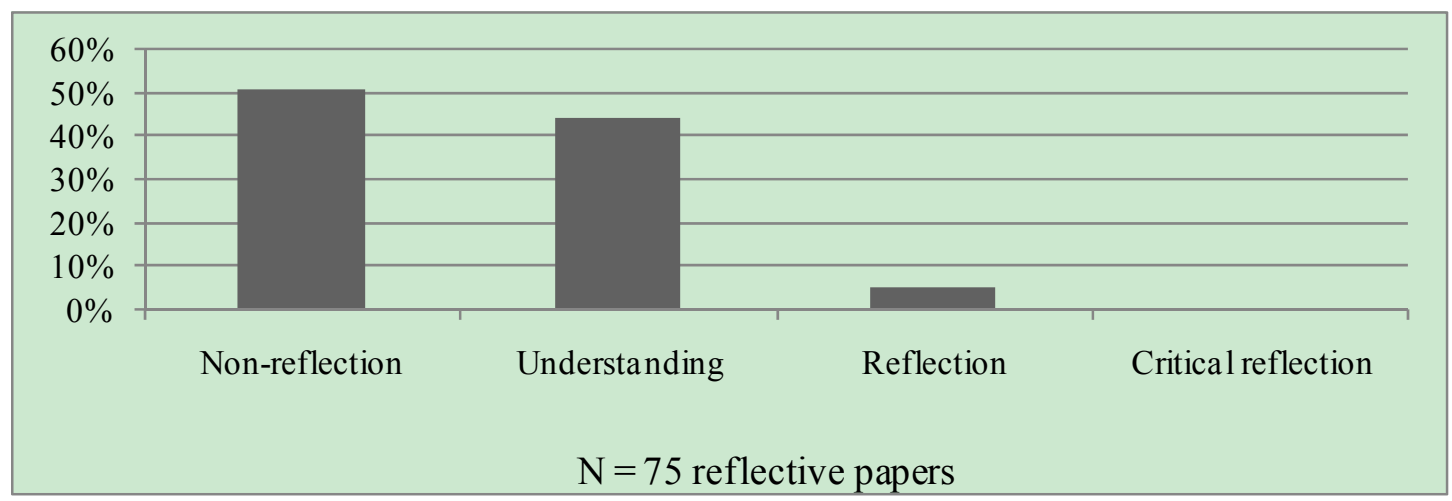

Figure 1. Percentage of essays by level of reflection

To find out if there was a change in the level of reflection of the papers throughout time, the first and the last essays of each participant were compared. Approximately $40 \%$ of the participants continued to write in the 'non-reflection' mode (Level 1); 47\% changed from 'non-reflection' to 'understanding' (Level 2); and 13\% changed from 'non-reflection' to 'reflection' (Level 3). None of the participants' papers showed evidence of a critical reflection (Level 4). These findings are depicted on Figure 2.

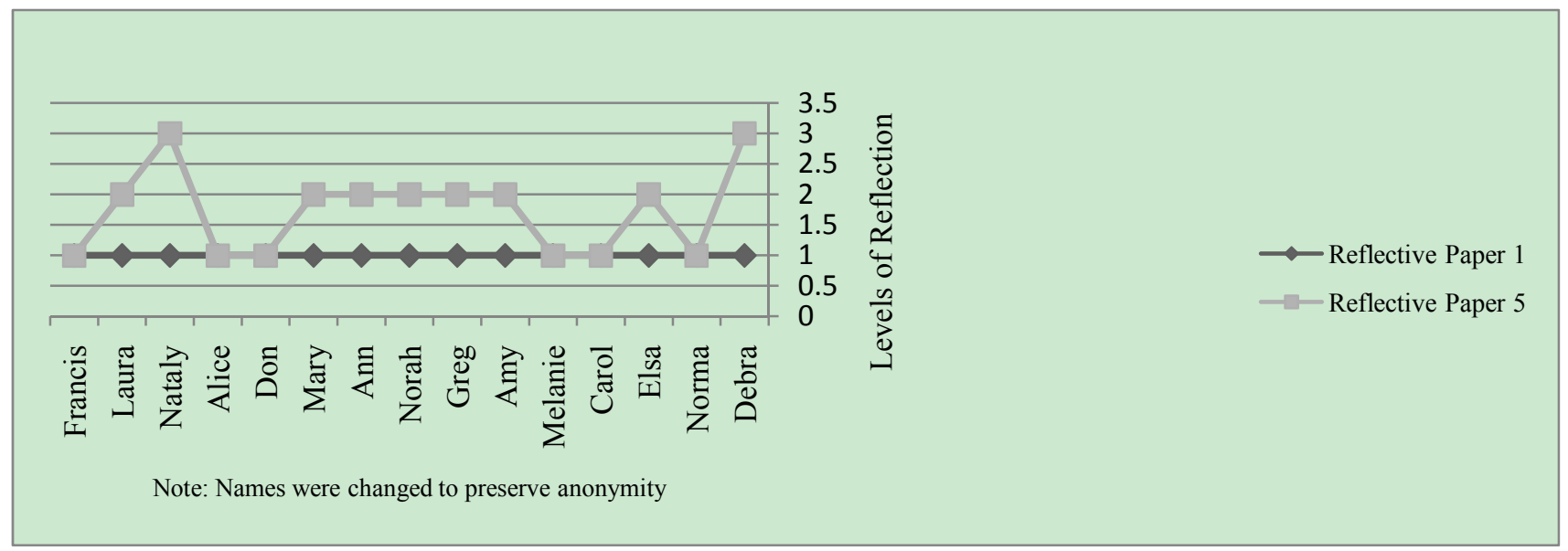

Figure 2. Levels of reflection in the first and last paper 
The papers that were classified as 'non-reflection' were focused on describing a learning activity and the problems encountered, without connecting the situation with a concept or theory. For example, one participant pointed to the need for her to use a variety of teaching methods because the one she used was not effective due to the learning styles and levels of proficiency of her students. Another participant stated that because the textbooks required by the school were intended for bilingual learners rather than for learners of English as a foreign language, her students were unable to comprehend the readings. She rationalized by commenting on the importance of ensuring active participation of students to create interest, in spite of the inadequate textbooks. In looking at the 'non-reflection' essays, it seems that participants were merely identifying problems and uncovering possible reasons. They did not explain how their readings and field experiences actually affected them, impacted them, or changed their thinking.

The papers that were classified as 'understanding' went a bit further because participants showed that they grasped a concept. One participant reflected on how learning the concept of critical period made her aware of the importance of using audio-materials to give students opportunities to hear native speakers. She noticed that audio-materials compensated her pronunciation difficulties as non-native speaker of English and helped students acquire native-like pronunciation at an age in which native-like pronunciation is more easily acquired. Another participant referred to the concept of scaffolding when discussing how group work helped her students learn from each other. She realized that grouping students in different ways gave different opportunities for scaffolding, "because learners know different types of things".

The two essays classified as 'reflection' included personal insights that went beyond book theory. The first participant discussed the concept of comprehensible input. She described the criteria she used for the selection of reading material for her students and the difficulties she encountered when deciding on input that were comprehensible for her 28 students. Then, she reflected on her own difficulties to understand the SLA course input that, she considered, at times was above her level of comprehension and seemed so straightforward for most of the other members of the SLA class. The second participant, whose work was classified as 'reflection', designed a writing activity to collect her students' papers as evidence of their interlanguage. Her purpose was to look for ways to make students aware of correct forms before the incorrect ones would fossilize. She commented on the difficulties to analyze her students' interlanguage and questioned if the reason was her own interlanguage.

'Critical reflection', in which the writer gives evidence of a change in understanding of a key concept or phenomenon, was not found on the papers collected for this study. This type of reflection seems to be more demanding, requiring knowledge, experience and awareness of the interplay of the various factors that result in a particular learning situation. Critical reflection appears to require more time to develop.

\subsection{Difficulties in Reflective Writing}

To reveal the difficulties that the participants encountered when writing the reflective papers, interviews were held with three of the participants. All three participants mentioned that they had struggled with reflective writing. Alice, whose paper was classified as 'non-reflection', mentioned that she easily lost her thought process during writing due to her elementary proficiency in English. The following is an excerpt of her comments:

The reflection papers were the hardest part of the course. I felt I could not express all I wanted because my English is not good enough for that yet. I had to put a lot of time on the assignments. I think the reflection part should have been in Spanish, at least at the beginning. Sometimes I first wrote ideas or paragraphs in Spanish and then I translated them. Writing is hard for me but writing in English is even harder. My mind was focused on how to say things in English and I lost track of what I wanted to say. (Alice, E1)

Another difficulty was related to reflective writing as a distinct academic genre. Amy, whose paper was classified as 'understanding', mentioned she had problems with the level of formality of her writing. It seems that she made an effort to find the right balance between formal and informal styles. The following is a segment of her comments during the interview.

For me they were very difficult to do [the reflective papers]. Especially in the part where you have to show what you learned. You have to kind of talk to yourself, but you also have to write more formally for the instructor. You don't want to be too informal, so you write it and then you go back to find more formal words and re-write it. At the beginning I thought it was going to be straightforward, I understood the examples. But then, it takes time to write your reflections in a more academic way. (Amy, W2)

The application of theory to practice was the concern of Nataly, whose paper was classified as 'reflection'. The use of theory is thought to be a valuable tool for teaching more effectively. However, working from abstract (principles) to concrete (practical situations) may be problematic for students with an inductive learning approach. Nataly 
found it difficult to put into operation with her students the kind of language proficiency required in academic settings. The following were her concerns.

The most difficult part is when you have to join the concepts with what you do in class. Maybe we do it every day without thinking, you know, why did I do this? Or oh, this is what happened, this is how it works. But when you have to do it in a planned fashion, when you have to do something differently that matches with what you are reading, it seems awkward. I can do the concepts fine, and I can describe what happens in my class, but linking the concepts with what you do in the classroom and getting something extra of it, something more structured, it's difficult... I want to develop the CALP [Cognitive Academic Language Proficiency] of my students. I selected from a reading those words that were of a more academic type, more abstract. I explained the meanings of words to make the students familiar with them and I gave many examples. When it came to the reading, it was as if we had done nothing. They couldn't remember the meanings. I was disappointed, but on my reflection I focused on the positive part. Students liked the idea of going over the words before reading. (Nataly, D. 1)

Academic language acquisition requires more than understanding of content area vocabulary. It includes other skills such as comparing, classifying, synthesizing, evaluating, and inferring. Students need time and support to become proficient in academic areas and Nataly did not seem to grasp the complexity of developing academic language proficiency.

Nataly mentioned another difficulty, related to the way in which feedback was provided. She seemed to be expecting more direct and specific corrections on her texts that guided her into a new way of writing. Probably, comments more focused on content, organization and language would have satisfied her need for clearer and more detailed guidance. The following is a fragment of her comments.

It would have been easier if the instructor helped us a bit by giving us more feedback. Actually, she did give us feedback on our papers, but she did not point to what we needed to do or how to improve our reflective writing. I don't think she was of much help. We needed more help. (Nataly, D. 2)

As the results suggest, reflective writing involves a variety of elements, mixed in a complex way. In this case study the participants revealed that their difficulties revolved around their language proficiency, their writing skills, their in-depth analysis skills and the need for more productive feedback.

\subsection{Perceived Usefulness of Reflective Writing}

a) Reflective writing allows participating more actively in the course.

Written reflections facilitated the student teachers' participation and engagement in course materials. Alice, for example, found she could take part in class discussion more fully after she had previously written something related to the topic under discussion. The following interview fragment shows her views.

For me, it [the reflective writing activity] was useful to participate in class. It happens to me a lot, I don't have much to comment and I feel I should be saying something. After writing the reflection paper I had a type of backup that helped me in the discussions. If I didn't have anything to say, it might look like I wasn't participating, but then my reflection paper gave me a chance to say something and to give real examples. (Alice, U. 1)

In-service teachers, as adult learners, bring a number of experiences, both personal and professional, that become the back-drop for their learning how to teach English. Connecting what they already know with new knowledge is facilitated when they are given opportunities for oral interaction. Not all learners, however, find it easy to speak out in class and it seems that reflective writing offers the opportunity for participation to every learner, not just those who are more socially confident or proficient in the second language.

Reflective writing also encouraged thorough completion of course reading assignments. Nataly seemed to value taking a second look at both what she was reading and her teaching experiences. This process involved understanding concepts and deciding whether the class material made sense to her in light of her teaching experiences. The following are her views on how reflective writing was useful to her.

Well, I guess for me it helped with the information in the readings because I tend to read quickly and I skip important things. And then if I have to sit down and actually put it in writing, I go back and look more carefully at it, and then I also look carefully at what I do in class, so I can find out how it applied to my situation. (Nataly, U. 1)

Amy also found that reflective writing was useful in terms of taking a stance in relation to theories and teaching methods. By having to reflect on the connections between theory and practice, participants expressed beliefs, feelings, values and dispositions to act in certain ways. Amy said she felt more confident on what she had learned once she had written about it. Then she added, "It [reflection writing] almost forces you to have an opinion and to give details about it. You end up understanding the concepts and stuff". (Amy, U. 1) 
b) Reflective writing contributes to improving written communication skills.

Reflection papers improved academic writing skills, according to the views of Amy. When asked about her impressions of the effects of writing reflective papers in class, she considered that she had made progress in her communication skills. The following was her point of view.

I handed over a 3-page paper on time but I had changed everything a million times because she [the instructor] wouldn't get the whole picture. But then I thought, I have to be clear and concise. It made us write better, I think. (Amy, W. 2)

Alice also pointed to the improvement of her writing skills stating that she thought that academic writing was the objective of the course. The following are her comments.

I thought it was the purpose of the reflection papers, to advance our writing skills, to use them in this and in all our courses. The instructor was kind of testing how to teach us to write because in writing you demonstrate what you learned. (Alice, W. 1)

As teacher educators we are challenged to actively involve student teachers in learning. They bring a wealth of lived experiences to the classroom, but might not have had educational experiences that challenged them to think and write critically. Reflective writing may provide opportunities to acquire new knowledge and also enhance their basic writing skills.

Despite the participants' indications of the usefulness of reflective writing, it seems that it is not something they would do on their own initiative. During the interviews the student teachers expressed that written reflection became somewhat burdensome as the course progressed. Alice said that she did not like to write, and she felt it was something she did only because it was 'forced' upon her. Amy considered that although reflective writing was helpful, she did not see herself doing it in the future. Nataly seemed to agree that it was not always 'fun to write'.

\section{Conclusions}

This case study investigated the level of reflection in the written work of 15 Mexican English language teachers taking a Masters' degree course. It also examined the difficulties they encountered when writing and the usefulness they attributed to reflective writing. We found that in spite of the training received, none of the participants attained the level of 'critical reflection'. A little more than half of the student teachers progressed from a level of 'non-reflection' in the first essay, to a level of 'understanding' or 'reflection' in the last essay they wrote for the course.

The problems came from a lack of familiarity with reflective writing; this academic genre is not common in the Mexican education system and participants were experiencing it for the first time. Difficulties also arose for those who had a low level of proficiency in English language and those with an inductive style of learning. The course adopted a deductive approach in which the participants learned the concepts and theories of SLA first, and then used them to reflect on their teaching experience. Some teachers prefer working from concrete situations to theoretical explanations rather than the other way around. Also, participants could have had fewer problems if more productive feedback were provided.

Reflective writing was considered useful because it fostered course involvement, helped shy students participate in class discussion, improved academic writing, and facilitated the adoption of a position in relation to SLA theories.

\section{Implications for Teaching}

Given that professional or academic reflection is not intuitive and requires specific pedagogic intervention to do well, we believe a program-wide approach is essential. This study involved the use of reflection as a teaching/learning strategy in one course in which participants were using it for the first time. Reflective writing should give better results when it is adopted across several courses, through a systematic, developmental approach. We must be mindful that reflection is a long-term, complex process and to become reflective writers, students require time, experience, and effort.

Structuring the reflection process appears to be indispensable for maximizing the positive qualities identified by participants. This structuring includes providing specific prompts or questions to focus student examination of issues most relevant to course content; and incorporating the process approach to writing in which participants have ample opportunity to receive feedback from instructor and peers. Student writers benefit from peer feedback before submitting their papers because they get a chance to establish bonds with fellow students and a structured environment to think critically and see the application of their ideas. Peer feedback may also be a way to ensure that students revise their writing. If well planned and executed, peer feedback can be an effective method of 
engaging students in the process of evaluating the reflection of others and, by extension, reconsidering their own reflective writing.

Successful writing requires sustained scaffolding, particularly when the writers are not using their first language. More improvement can occur when participants are taught to identify linguistic features in their own writing. Providing students with examples of reflective writing did not aid their attempts to write reflectively. Perhaps, teaching students how to identify, compare and contrast the features of evaluative or critical reflection with the features of lower level descriptive reflection or recounting would have made a greater impact on their reflective papers. Through such explicit demonstration and by giving participants opportunities to annotate these key features on samples and on their own papers, they could have been better supported to write reflectively. Such explicit scaffolding would have been useful in learning an academic genre that was new to them.

\section{Recommendations for Future Research}

Writing reflectively is a difficult task when writing in the first language and it turns even more complex when using a second language. One of the participants mentioned that her language proficiency was the source of her difficulties and suggested the use first language, at least in the beginning stages of developing a reflective paper. It would be interesting to compare the level of reflection that student teachers attain in their first and the foreign language, and to find out if using the first language in the beginning stages of learning the genre impacts the way they perform subsequently in English.

Some students were well able to identify their personal experience of the readings ("As I read the article, I was thinking about an activity I could do in my class" or "As I read I realized I was far from being bilingual"), make a connection between their experience with the theories being studied, and connect that to what they were actually doing in professional practice. However, many students did not seem to build this links. Future studies could focus on analyzing the conditions and factors that facilitate the connection between theoretical principles and personal experiences, from the point of view of the participants.

The conditions under which reflective writing takes place can have a powerful influence on what is produced and the extent to which writers can engage in critical reflection. For example, we know that great care needs to be taken about how reflective writing relates to assessment. In this study students were aware that as long as they submitted a paper, their course grades were not negatively affected. The question arises as to whether this influenced those that continued to write in a 'non-reflection' mode. Other studies could investigate if peer assessment, for example, produces changes in the level of reflection of second language writers.

Finally, the assessment scheme developed by Kember, et al. (2008) seemed quite appropriate to evaluate the level of reflection portrayed in the participants' essays, written in English as a foreign language. Future research could further investigate the applicability of the instrument to reflection papers written in Spanish as a first or a second language.

\section{References}

Bailey, K. M., Curtis, A., \& Nunan, D. (2001). Pursuing professional development: The self as source. London: Heinle \& Heinle.

Barkhuizen, G. (2008). A narrative approach to exploring context in language teaching. ELT Journal, 62(3), 231-239. http://dx.doi.org/10.1093/elt/ccm043

Bartlett, L. (1990). Teacher development through reflective practice. In J. C. Richards, \& D. Nunan (Eds.), Second Language Teacher Education (pp. 202-214). Cambridge: Cambridge University Press.

Bissex, G. L., \& Bullock, R. H. (1987). Seeing for ourselves. Case study research by teachers of writing. Portsmouth, NH: Heineman.

Bissex, G. L. (1990). Small is beautiful: Case study as appropriate methodology for teacher research. In D. A. Daiker \& M. Morenberg (Eds.), The writing teacher as researcher (pp. 52-75). Portsmouth, NH: Boynton / Cook Publishers.

Boud, D. (2001). Using journal writing to enhance reflective practice. New Directions for Adult and Continuing Education, 90, 9-17. http://dx.doi.org/10.1093/elt/ccm043

Boyd, E. M., \& Fales, A. W. (1983). Reflective learning. Journal of Humanistic Psychology, 23(2), 99-117.

Burns, A. (1999). Collaborative action research for English language teachers. Cambridge: Cambridge University Press.

Burns, A. (2009). Doing action research for English language teachers: A guide for practitioners. NY: Routledge. 
Colton, A., \& Sparks-Langer, G. M. (1993). A conceptual framework to guide the development of teacher reflection and decision-making. Journal of Teacher Education, 44, 45-54.

Crandall, J. (2000). Language teacher education. Annual Review of Applied Linguistics, 20, 34-55.

Day, C. (1993). Reflection: A necessary but not sufficient condition for professional development. British Educational Research Journal, 19, 83-93. http://dx.doi.org/10.1080/0141192930190107

Day, R. R. (1990). Teacher observation in second language teacher education. In J. C. Richards, \& D. Nunan (Eds.), Second Language Teacher Education (pp. 43-61). Cambridge: Cambridge University Press.

Dubin, F., \& Wong, R. (1990). An ethnographic approach to in-service preparation: The Hungary file. In J. C. Richards \& D. Nunan (Eds.), Second Language Teacher Education (pp. 282-292). Cambridge: Cambridge University Press.

Farrell, T. (2004). Reflective practice in action. Thousand Oaks, CA: Corwin Press.

Fink, L. D. (2003). Creating significant learning experiences: An integrated approach to designing college courses. San Francisco: Jossey-Bass.

Fund, Z., Court, D., \& Kramarski, B. (2002). Construction and application of an evaluative tool to assess reflection in teacher-training courses. Assessment and Evaluation in Higher Education, 37(6), 485-499. http://dx.doi.org/10.1080/0260293022000020264

Glaser, B. G., \& Strauss, A. L. (1967). The discovery of grounded theory. Strategies for qualitative research. Chicago, IL: Aldine Publishing Company.

Gobierno del Estado de Tamaulipas. (2005-2010). Programa estatal de desarrollo educativo, Tamaulipas. México: GET.

Handal, G., \& Lauvas, P. (1987). Promoting reflective teaching. Milton Keines: SRHE.

Hatton, N., \& Smith, D. (1995). Reflection in teacher education: Towards definition and implementation. Teaching and Teacher Education, 11(1), 33-49.

Hiebert, J., Gallimore, R., \& Stigler, J. W. (2002). A knowledge base for the teaching profession: What would it look like and how can we get one? Educational Researcher, 31(5), 3-15.

Ho, B., \& Richards, J. C. (1993). Reflective thinking through teacher journal writing: Myths and realities. Prospect: An Australian Journal of Teaching/Teachers of English to Speakers of Other Languages, 8(3), 25-40.

Jay, J. K., \& Johnson, K. L. (2002). Capturing complexity: A typology of reflective practice for teacher education. Teacher and Teacher Education, 19, 73-85.

Kember, D., McKay, J., Sinclair, K., \& Wong, F. K. Y. (2008). A four-category scheme for coding and assessing the level of reflection in written work. Assessment \& Evaluation in Higher Education, 33(4), 369-379. http://dx.doi.org/10.1080/02602930701293355

King, P. M., \& Kitchner, K. S. (2004). Reflective judgment: Theory and research on the development of epistemic assumptions through adulthood. Educational Psychologist, 39(1), 5-18.

Lantolf, J. P. (2000). Sociocultural theory and second language learning. Oxford: Oxford University Press.

Larrivee, B. (2008). Development of a tool to assess teachers' level of reflective practice. Reflective Practice, 9(3), 341-360.

Larsen-Freeman, D. (2007). Reflecting on the cognitive-social debate in second language acquisition. The Modern Language Journal, 91, 773-787.

Lee, I. (2007). Preparing in-service English teachers for reflective practice. ELT Journal, 61(4), 321-329. http://dx.doi.org/10.1093/elt/ccm022

Luk, J. (2008). Assessing teaching practicum reflections: Distinguishing discourse features of the "high" and "low" grade reports. System, 36(4), 624-641.

MacNealy, M. S. (1999). Strategies for empirical research in writing. Needham Heights, MA: Allyn \& Bacon.

Mezirow, J. (1998). On critical reflection. Adult Education Quarterly, 48(3), 185-198.

Nunan, D. (1990). Action research in the language classroom. In J. C. Richards, \& D. Nunan (Eds.), Second Language Teacher Education (pp. 62-81). Cambridge: Cambridge University Press.

Patton, M. Q. (2002). Qualitataive research and evaluation methods. Thousand Oaks, CA: Sage Publications. 
Plack, M. M., Driscoll, M., Blissett, S., McKenna, R., \& Plack, T. P. (2005). A method for assessing reflective journal writing. Journal of Allied Health, 34(4), 199-205.

Ponnudurai, J. P., Wha, Y. P., \& Abdullah, H. (2002). Reflective writing among pre-service teacher trainees of Institut Perguruan Bahasa-Bahasa Antarabangasa. Jurnal Pendidikan IPBA, 2(5), 24-42.

Reagan, T. G., Case, C. W., \& Brubacher, J. W. (2000). Becoming a reflective educator: How to build a culture of inquiry in the schools. Thousand Oaks, CA: Corwin Press.

Richards, J. C., \& Lockhart, C. (1996). Reflective teaching in second language classrooms. Cambridge: Cambridge University Press.

Richards, J. C., \& Farrell, T. S. C. (2005). Professional development for language teachers: Strategies for teacher learning. Cambridge: Cambridge University Press.

Rodgers, C. (2002). Defining reflection: Another look at John Dewey and reflective thinking. Teachers College Record, 104(4), 842-866. http://dx.doi.org/10.1111/1467-9620.00181

Russell, T. (2005). Can reflective practice be taught? Reflective Practice, 6(2), 199-204.

Schön, D. (1987). Educating the reflective practitioner: Toward a new design for teaching and learning in the professions. San Francisco: Jossey Bass.

Shin, S. J. (2006). Learning to teach writing through tutoring and journal writing. Teachers and Teaching: Theory and Practice, 12(3), 325-345.

Spada, N. (1990). Observing classroom behaviors and learning outcomes in different second language programs. In J. C. Richards, \& D. Nunan (Eds.), Second Language Teacher Education (pp. 293-310). Cambridge: Cambridge University Press.

Spalding, E., \& Wilson, A. (2002). Demystifying reflection: A study of pedagogical strategies that encourage reflective journal writing. Teachers College Record, 104, 1393-1421. http://dx.doi.org/10.1111/1467-9620.00208

Sparks-Langer, G. M., Simmons, J. M., Pasch, M., Colton, A., \& Starko, A. (1990). Reflective pedagogical thinking: How can we promote it and measure it? Journal of Teacher Education, 41(5), 23-32. http://dx.doi.org/10.1177/002248719004100504

Strauss, A., \& Corbin, J. (1998). Basics of qualitative research. Thousand Oaks, CA: Sage Publications.

Van Lier, L. (1988). The classroom and the language learner: Ethnography and second-language classroom research. NY: Longman.

Van Manen, M. (1977). Linking ways of knowing with ways of being practical. Curriculum Inquiry, 6(3), 205-228. http://dx.doi.org/10.2307/1179579

Wallace, M. J. (1991). Training foreign language teachers: A reflective approach. Cambridge: Cambridge University Press.

Wallace, M. J. (1998). Action research for language teachers. Cambridge: Cambridge University Press.

Weimer, M. (2002). Learner-centered teaching. San Francisco, CA: Jossey-Bass.

Wong, F. K. Y., Kember, D., Chung, L. Y. F., \& Yan, L. (1995). Assessing the level of student reflection from reflective journals. Journal of Advanced Nursing, 22(1), 48-57. http://dx.doi.org/10.1046/j.1365-2648.1995.22010048.x

Woodfield, H., \& Lazarus, E. (1998). Diaries: A reflective tool on an INSET language course. ELT Journal, 52(4), 315-322. http://dx.doi.org/10.1093/elt/52.4.315 


\title{
Appendix 1
}

\author{
Research Instruments
}

Scheme to Assess Levels of Reflection in Written Work

(C) 2008 David Kember, Jan McKay, Kit Sinclair and Francis Wong

\section{Non-reflection}

- The answer shows no evidence of the student attempting to reach an understanding of the concept or theory which underpins the topic.

- Material has been placed into an essay without the student thinking seriously about it, trying to interpret the material, or forming a view.

- Largely reproduction with or without adaptations, of the work of others.

\section{Understanding}

- Evidence or understanding of a concept or topic.

- Material is confined to theory.

- Reliance upon what was in the textbook or the lecture notes.

- Theory is not related to personal experiences, real-life applications or practical situations

Reflection

- Theory is applied to practical situations.

- Situations encountered in practice will be considered and successfully discussed in relationship to what has been taught.

- There will be personal insights which go beyond book theory.

Critical reflection

- Evidence of a change in perspective over a fundamental belief of the understanding of a key concept or phenomenon.

- Critical reflection is unlikely to occur frequently

\section{Interview Protocol}

You were invited to this interview because you agreed to participate in a classroom study on reflective writing. I will ask you a few questions related to your opinions and feelings toward the course. Answers will not be considered as correct or incorrect, they will simply reflect the ways in which you perceive the course and the written work you had to do, and that's what we are interested in. Let's start.

1. Reflective writing can show different levels of thinking about the connection between theory and practice.

How did you find the opportunities to make this connection?

Could you give some examples?

2. Were there any difficulties when writing for the course?

What were your difficulties?

Please give examples.

Why do you think you had no difficulties when writing for this course?

3. How useful did you find the writing part of the course?

How was it useful? Could you give me an example in which the course was useful to you?

Why wasn't it useful? What could have helped you more? 